\title{
Role of the Zinc Nutritional Status on Main Physiological Bioindicators of the Pecan Tree
}

\author{
Angélica Anahí Acevedo-Barrera1, Esteban Sánchez², Rosa María Yáñez-Muñoz ${ }^{3}$, \\ Juan Manuel Soto-Parra ${ }^{3}$, Ángel Lagarda-Murrieta1 ${ }^{*}$, Vicente de Paul Álvarez-Reyna1, \\ Eduardo Madero-Tamargo ${ }^{1}$, Alejandro Moreno-Resendez ${ }^{1}$ \\ ${ }^{1}$ Universidad Autónoma Agraria Antonio Narro, Torreón, México \\ ${ }^{2}$ Centro de Investigación en Alimentación y Desarrollo A.C. Unidad Delicias, Delicias, México \\ ${ }^{3}$ Facultad de Ciencias Agrotecnológicas, Universidad Autónoma de Chihuahua, Chihuahua, México \\ Email: *lagarda82@yahoo.com.mx
}

How to cite this paper: Acevedo-Barrera, A.A., Sánchez, E., Yáñez-Muñoz, R.M., Soto-Parra, J.M., Lagarda-Murrieta, Á., de Paul Álvarez-Reyna, V., Madero-Tamargo, E. and Moreno-Resendez, A. (2017) Role of the Zinc Nutritional Status on Main Physiological Bioindicators of the Pecan Tree. Agricultural Sciences, 8, 1327-1336. https://doi.org/10.4236/as.2017.812096

Received: November 10, 2017 Accepted: December 25, 2017 Published: December 28, 2017

Copyright $\odot 2017$ by authors and Scientific Research Publishing Inc. This work is licensed under the Creative Commons Attribution International License (CC BY 4.0).

http://creativecommons.org/licenses/by/4.0/

\begin{abstract}
The purpose of this study was to analyze the effect of $\mathrm{Zn}$ nutritional status on the content of pigments, nonstructural carbohydrates, foliage proteins and amino acids of the pecan tree, as possible bioindicators of $\mathrm{Zn}$ deficiency. The experimental design was completely random with three $\mathrm{Zn}$ nutritional statuses: Normal, Intermediate and Deficient, being selected considering visual symptomatology. On all three nutritional statuses, the concentration of photosynthetic pigments was determined as well as of total soluble proteins and amino acids. Obtained results indicate that $\mathrm{Zn}$ deficient nutritional status was characterized by minimum photosynthetic pigment, protein concentrations, maximum amino acid and nonstructural carbohydrate concentrations. While the normal $\mathrm{Zn}$ nutritional status presented maximum photosynthetic pigments, proteins concentrations, minimum amino acids and carbohydrate concentrations. On the other hand, intermediate $\mathrm{Zn}$ nutritional status was characterized by a medium level between the other two $\mathrm{Zn}$ nutritional statuses. Finally, we stress the fact that pigments, proteins, amino acids and nonstructural carbohydrates may be good physiological indicators related to $\mathrm{Zn}$ nutritional status on pecan trees.
\end{abstract}

\section{Keywords}

Carya illinoinensis, Bioindicators, Deficiency, Nutritional Stress

\section{Introduction}

Mexico is the world's second largest producer of pecan tree [Carya illinoinensis (Wangenh.) K. Koch], right behind the United States [1], with a cultivated sur- 
face of $114,464.17 \mathrm{ha}^{-1}$ and a production of 141 million $817 \mathrm{t}$., which are distributed in the northern part of the country in the states of Chihuahua, Coahuila, Sonora, Durango and Nuevo León [2]. However, a constraining factor in terms of pecan tree productivity is Zinc ( $\mathrm{Zn})$ deficiency since it is a crop extremely sensitive to $Z n$ insufficiency [3] [4].

In Mexico, the predominating type of soil in pecan tree producing regions is calcareous soil [3] [4] [5] with 7.0 to $8.6 \mathrm{pH}$ levels and a high content of carbonate. Such characteristics limit the availability of $\mathrm{Zn}$ [3], an element required especially during shoot lengthening [6] and in normal cellular metabolism [7].

Under such soil conditions, as $\mathrm{pH}$ increases, extractable $\mathrm{Zn}$ decreases due to the increase in adsorption capacity, formation of hydrolyzed $\mathrm{Zn}$ forms, and possible chemisorption of calcium carbonate and coprecipitation of iron oxide [8]. In Mexico, more than $50 \%$ of soil has low $\mathrm{Zn}$ levels, while only a low percentage has $\mathrm{Zn}$ levels considered as high or just enough for adequate crop nutrition [9].

A level below $60 \mathrm{ppm}$ in pecan tree leaves cultivated in alkaline soils of the northern region of Mexico is considered as deficient [3] [5] and shows visual symptoms in levels approximately below $15 \mathrm{mg} \mathrm{g}^{-1}$ of dry weight [6]. Below the required inferior level, there is also inhibition of plant growth [6] [10], biochemical and physiological changes, as well as morphological and structural differences [11] due to physiological stress caused by dysfunctional metabolic functions on which $\mathrm{Zn}$ has an important role [8]. Within the functions that present alterations are carbohydrate, lipids and nucleic acids metabolism, protein synthesis and reproductive development such as pollen formation, structural and functional integrity of biomembranes, photosynthetic $\mathrm{C}$ metabolism and chlorophyll biosynthesis [4] [7] [12].

On the other hand [4] [13], Zn deficiency was reported to impact pecan tree metabolism and physiology, inhibiting growth, protein synthesis and changes on amino acids levels. Changes in pigment, nonstructural carbohydrates, proteins and foliage amino acid levels can be used as $\mathrm{Zn}$ deficiency bioindicators in pecan trees. However, there is little information regarding the influence of these bioindicators in $\mathrm{Zn}$ deficiency in pecan trees. Therefore, the purpose of this study was to analyze the effect of $\mathrm{Zn}$ nutritional status on pigment, nonstructural carbohydrates, proteins and foliage amino acids content in pecan tree as possible bioindicators of $\mathrm{Zn}$ deficiency.

\section{Materials and Methods}

\subsection{Study Area}

The study was carried out in the "Tierra Blanca" orchard in Matamoros, Coahuila de Zaragoza, Mexico. The county has $25^{\circ} 25^{\prime}$ latitude, $103^{\circ} 18^{\prime}$ longitude and is at 1150 meters above the sea level. Weather in the county has very dry, very warm and warm subtypes. Average yearly temperature is $22^{\circ} \mathrm{C}$ to $24^{\circ} \mathrm{C}$ and average yearly rainfall is within the range of 200 to 300 millimeters, with a rainfall 
regime in the months from May to October. Prevailing winds blow from the south at a speed from 27 to $44 \mathrm{~km} \mathrm{~h}^{-1}$. Frost frequency is of 0 to 20 days and hail from 0 to 1 day.

\subsection{Plant Material}

The experiment was executed during the month of May 2017 in trees of 6 years of age from the Burkett variety. This variety is characterized by 42 walnuts per pound and a nut percentage of 59\%. These trees were located in the nursery within the orchard, with the purpose of rejuvenating the oldest trees. The trees were located at a distance of $1 \times 50 \mathrm{~cm}$. Furrows were covered with plastic protective sheets. Irrigation was distributed by means of dripping once per week for a period of 12 hours, from the month of March to mid-October. The area was managed with minimum tilling.

\subsection{Experiment Design}

A fully random experimental designed was used, with three $\mathrm{Zn}$ nutrition status: Normal, Intermediate and Deficient (Figure 1) and five repetitions per nutrition status. Zn nutrition status was selected in accordance with visual symptomatology presented in terms of $\mathrm{Zn}$ nutrition status (Figure 1).

\subsection{Plant Sampling}

The plant material was selected in accordance with leaflet appearance in terms of color, shape and branch size due to $\mathrm{Zn}$ nutrition status. Three nutrition statuses were selected: (a) Normal, (b) Intermediate and (c) Deficient (Figure 1).

Per each nutritional status and its respective repetitions, 40 leaflets of the

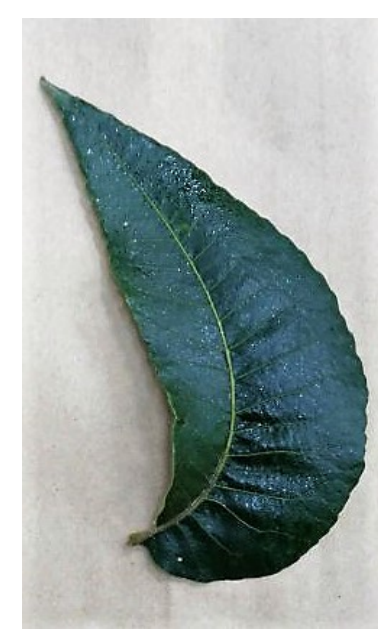

(a)

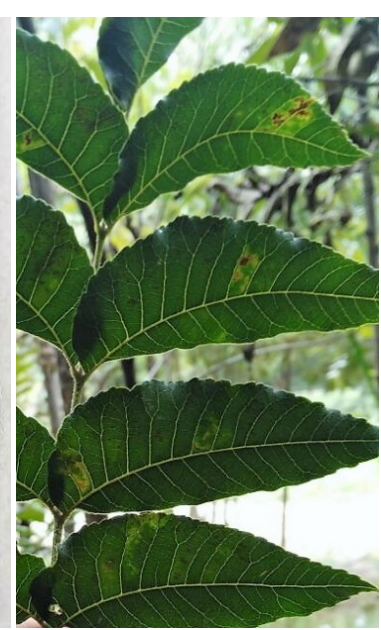

(b)

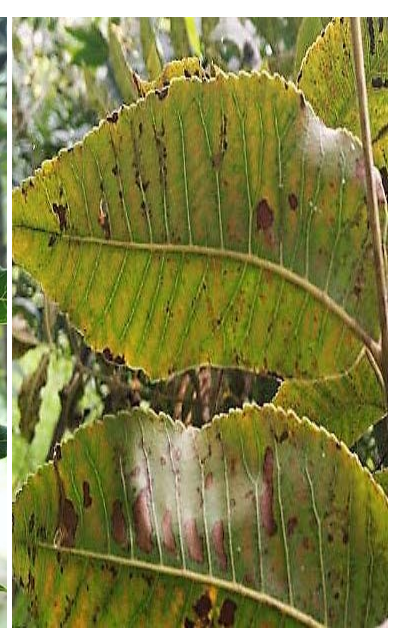

(c)

Figure 1. Zn nutrition status in pecan tree leaves in accordance with its symptomatology. (a) Normal: even green leaf. (b) Intermediate: leaves with early stage Zn deficiency symptomatology showing spotted regions, general internode chlorosis and early stage necrosis. (c) Deficient: leaves with serious $\mathrm{Zn}$ deficiency symptoms showing chlorosis, necrosis and leaves with undulate margins. 
growth year leafs were taken in the mid part of the treetop from all four compass points. Plant material was placed on transparent plastic bags and was frozen at $-30^{\circ} \mathrm{C}$ to then determine photosynthetic pigments, nonstructural carbohydrates, proteins and total soluble amino acids concentrations.

\subsection{Physiological Indicators}

\subsubsection{Determination of Total Chlorophyll}

The total chlorophyll concentration was quantified by extraction with methanol and reading the absorbance. For this, $60 \mathrm{mg}$ of petiolules of $5 \mathrm{~mm}$ in diameter were weighed, placed in test tubes with $5 \mathrm{ml}$ of methanol, and left $24 \mathrm{~h}$ or more until total discoloration of the plant material. The process was made at ambient temperature in darkness. Afterwards, the absorbance was read in $652 \mathrm{~nm}$, the total chlorophyll content was expressed in $\mathrm{mg} \mathrm{g}^{-1}$ fresh weight (FW) [14]. The foliar pigment content was calculated using the following equations:

$$
\begin{gathered}
\text { Chl } a=[15.65(\text { A666 })-7.34(\text { A653 })] \\
\text { Chl } b=[27.05(A 653)-11.21(A 666)] \\
\text { Carotenos }=[(1000 A 470)-2.86(\text { Chl } a)-129.2(\text { Chl } b)] / 221
\end{gathered}
$$

\subsubsection{Quantification of Non-Structural Carbohydrates}

Carbohydrates were measured with appropriate adaptations being made for our plant material. A sample of $0.5 \mathrm{~g}$ fresh matter was homogenized twice with $95 \%$ ethanol (v/v) and washed with 70\% ethanol (v/v), followed by centrifugation at $1500 \mathrm{~g}$ at $2^{\circ} \mathrm{C}$ for $15 \mathrm{~min}$. Glucose, fructose, and sucrose were determined in the resulting supernatant by spectrophotometry at $650 \mathrm{~nm}$, using the colorimetric assay with anthrone. The total non-structural carbohydrates content was expressed in $\mathrm{mg} \mathrm{g}^{-1} \mathrm{FW}[15]$.

\subsubsection{Quantification of Amino Acids and Proteins}

The amino acids and proteins were determined after homogenization of $0.5 \mathrm{~g}$ fresh samples in $50 \mathrm{mM}$ cold $\mathrm{KH}_{2} \mathrm{PO}_{4}$ buffer at $\mathrm{pH} 7$ and centrifugation at 12,000 $g$ at $4^{\circ} \mathrm{C}$ for $15 \mathrm{~min}$. The resulting supernatant was used for the determination of total amino acids by the ninhydrin method; total free amino acids were expressed as $\mathrm{mg} \mathrm{g}^{-1} \mathrm{FW}$. Soluble protein was measured with Bradford G-250 reagent and expressed as $\mathrm{mg} \mathrm{g}^{-1} \mathrm{FW}$, using bovine serum albumin (BSA) as standard [16].

\subsection{Statistical Analysis}

Data were subjected to a simple ANOVA at $95 \%$ confidence, using [17]. Means were compared by Tukey test $(P \leq 0.05)$. The data shown are mean values \pm standard error (SE). Levels of significance were represented by ${ }^{*}$ at $P<0.05$, ${ }^{*} P$ $<0.01,{ }^{* * *}$ at $P<0.001$ and NS: not significant. 


\section{Results and Discussion}

\subsection{Leaf Pigments}

Photosynthetic pigments in pecan trees are indicators of Zinc nutrition status [14]. On this study, we found significant differences in terms of chlorophyll a and carotenes (Figure 2, $P<0.001$ ) concentration on all three Zn nutrition statuses (normal, intermediate and deficient). Maximum concentrations were found in the normal nutrition status, with increases of $38 \%$ and $40 \%$ respectively compared with the deficient nutrition status which presented minimum concentrations. In regards to chlorophyll b concentration, no significant differences were recorded in terms of the three $\mathrm{Zn}$ nutrition statuses. However, the normal nutrition status presented the highest concentration with a $31 \%$ increase compared to the deficient nutrition status which presented the lowest concentration. This matches with leaf symptomatology observed on field, both leaves with intermediate and deficient symptoms had chlorophyll a and b and carotene levels below those found on normal leaves (without symptoms).

The aforementioned can be related to lower $\mathrm{Zn}$ concentrations recorded in leaf analysis, with an average of $14.29 \mathrm{ppm}$. [3] found that $\mathrm{Zn}$ deficiency results in low leaf chlorophyll concentrations, having recorded $43 \mathrm{mg} \mathrm{L}^{-1}$ extractable chlorophyll contents with low Zn levels and internode chlorosis observed in field. For leaves with moderate and severe $\mathrm{Zn}$ deficiency, chlorophyll levels with lower SPAD units were registered as well [11], compared to those found on control leaves (38\% and $43 \%$ decreases, respectively).

Previous studies from [3] [10], indicate that Zn concentration, visual symptomatology and chlorophyll levels are closely related. [11] and [18] mention as well studies where it is confirmed that chlorophyll quantity and quality, aside from being directly related to photosynthetic activity, are closely linked to plant nutrition status. Both variables show a positive relationship. On our study, the

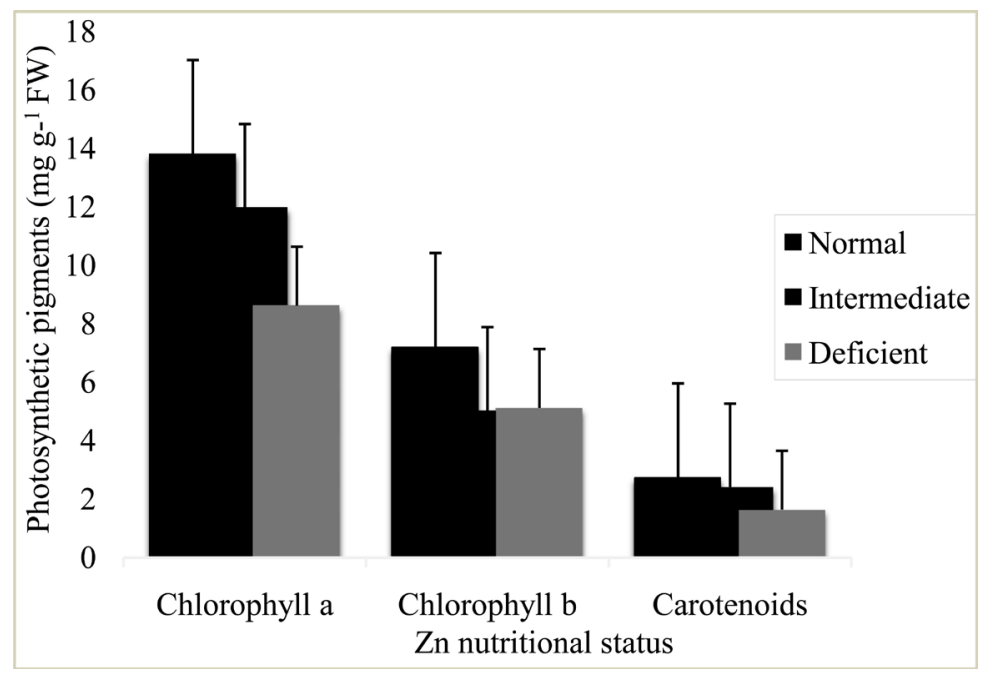

Figure 2. Concentration of photosynthetic pigments in pecan tree leaves according to the nutritional status of $\mathrm{Zn}$. Data are means \pm SE $(n=5)$. 
Table 1. Ratio between photosynthetic pigments depending on the nutritional status of Zn.

\begin{tabular}{ccccc}
\hline Zn nutritional status & Chla/Chlb & Chla/Carotenoids & Chlb/Carotenoids & Chl $_{\text {tot }} /$ Carotenoids \\
\hline Normal & 1.9181 & 5.0401 & 2.6285 & 7.6679 \\
Intermediate & 2.3398 & 4.9710 & 2.0872 & 7.0954 \\
Deficient & 1.7171 & 5.2561 & 3.1299 & 8.3171 \\
\hline
\end{tabular}

Chla $=$ Chlorophyll $\mathrm{a}, \mathrm{Chlb}=$ Chlorophyll $\mathrm{b}, \mathrm{Chl}_{\mathrm{tot}}=$ Chlorophyll total. The ratio was calculated by dividing the concentration of leaf pigments $\left(\mathrm{mg} \mathrm{g}^{-1} \mathrm{FW}\right)$.

obtained results were larger photosynthetic pigments on the normal nutrition status are shown, match with results obtained by [3] [10] [18] and [19]. Therefore, we can say that the content of photosynthetic pigments in the pecan tree can be considered an excellent bioindicator in regards to $\mathrm{Zn}$ nutrition status.

There is little information in regards to the effect of $\mathrm{Zn}$ nutrition status on photosynthetic pigment concentration of pecan trees. On our study, Chla/Carotene, $\mathrm{Chlb} /$ Carotene and $\mathrm{Chl}_{\text {tot }} /$ Carotene relationships revealed that carotene concentrations were higher to those of pigments in a deficient nutrition status compared to a healthy nutrition status (Table 1) [18]. In regards to Chla/Chlb and $\mathrm{Chl}_{\text {tot }}$ relationships, they showed the same behavior as individual pigments; having registered higher levels of chlorophyll and lower carotene concentrations (Figure 1). These results are similar to those presented by [18]. Such relationships reflect, in a broader sense, the efficiency of these pigments in photosynthesis. When Chla/Chlb are higher than the unit, pigment function during photosynthesis is adequate [18]. Regarding this behavior, [19] mention that it may be determined by a lower energy and metabolites demand to maintain growth, since whenever $\mathrm{Zn}$ is scarce there is a decrease in carbonic anhydrase, resulting in a lower photosynthetic rate.

\subsection{Total Soluble Amino Acids and Proteins}

$\mathrm{Zn}$ is closely related to $\mathrm{N}$ metabolism, therefore is also tightly related to $\mathrm{NO}_{3}$ assimilation final products on plants, which basically are amino acids and proteins. Proteins are synthesized from reduced amino acids [20]. On our study, significant differences were recorded for proteins in normal and deficient nutrition status, with a respective increase of $20 \%$, being the deficient nutrition status the one which registered a lower concentration. The opposite situation was presented in soluble amino acids concentration, where the highest concentration occurred in the deficient nutrition status, with a $49 \%$ increase compared to the normal nutrition status which registered the lowest concentration (Figure $3, P<$ 0.001 and Figure $4, P<0.01$ ). Previous studies have reported that on pecan trees one of the present metabolic responses to face stress caused by $\mathrm{Zn}$ deficiency is amino acid accumulation. As mentioned by [6], its concentration increases notoriously when $\mathrm{Zn}$ is deficient with the purpose of acting as osmotic agent and protecting the plant from stress conditions. [20] mentions that $\mathrm{Zn}$ plays an 


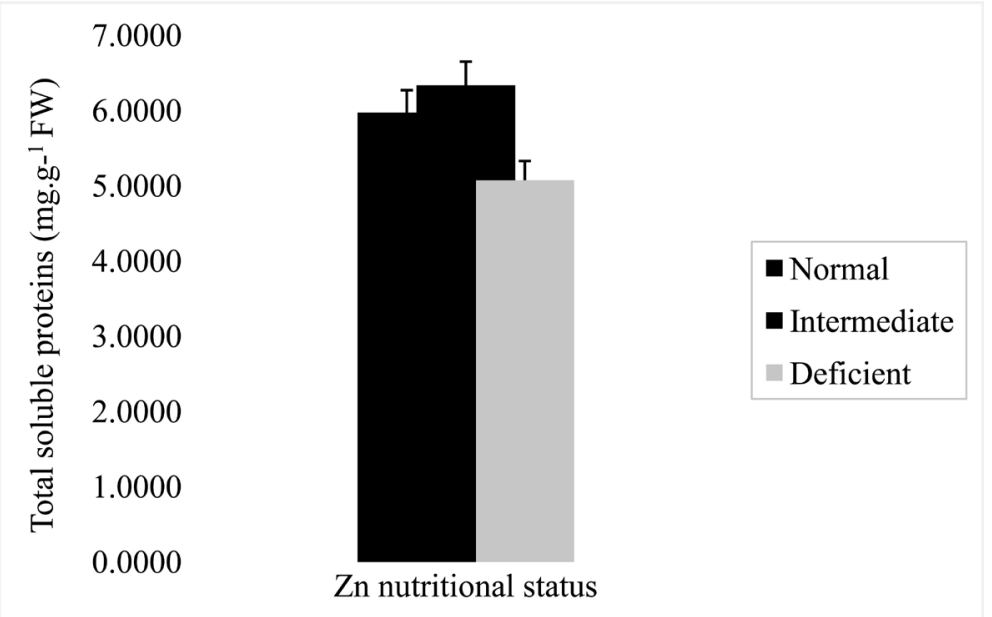

Figure 3. Concentration of total soluble proteins in pecan tree leaves according to the nutritional status of $\mathrm{Zn}$. Data are means \pm SE $(n=5)$.

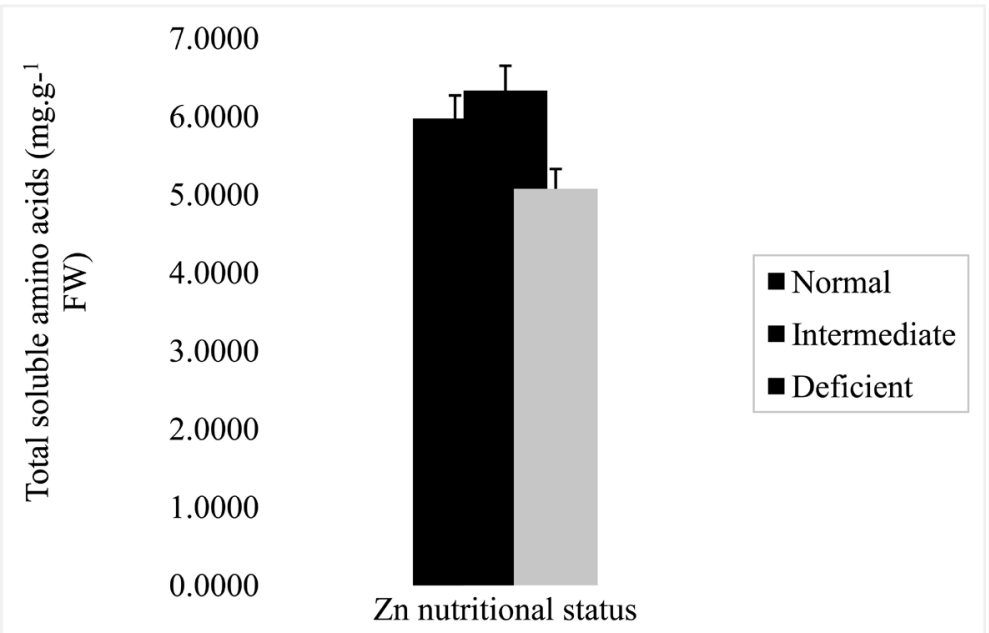

Figure 4. Concentration of total soluble amino acids pecan tree leaves according to the nutritional status of $\mathrm{Zn}$. Data are means \pm SE $(n=5)$.

important role in nitrogenous metabolism regulation and therefore in protein and amino acid concentration. When $\mathrm{Zn}$ is suppressed, protein concentration decreases and amino acid concentration increases. Once $\mathrm{Zn}$ is provided again, protein synthesis is induced which results in a decrease in ribonucleic acid (RNA). This is attributed to lesser activity of Zn polymerase, to lower ribosome structural integrity and to higher RNA degradation. The tendency of the deficient nutrition status compared to the normal status in terms of having a lower protein accumulation and higher amino acid accumulation matches with what is mentioned by [6] and [20]. Therefore, total soluble proteins and amino acid on pecan tree leaves can be good bioindicators regarding $\mathrm{Zn}$ nutrition status.

\subsection{Non-Structural Carbohydrates}

Carbohydrates are the final product of substances synthesized during photosyn- 


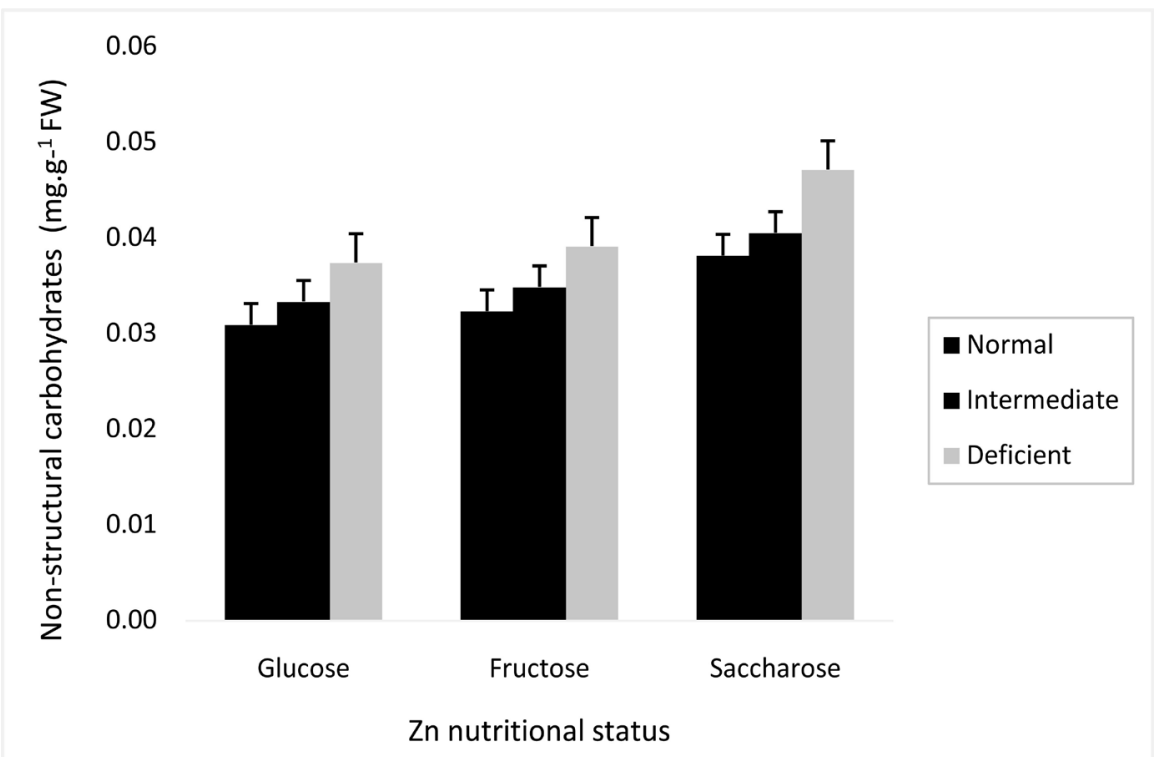

Figure 5. Concentration of non-structural carbohydrates pecan tree leaves according to the nutritional status of $\mathrm{Zn}$. Data are means \pm SE $(n=5)$.

thesis, during which chlorophyll intervenes actively [18]. Its concentration varies depending on nutrition conditions and tree phenological state [21]. On this study, we found significant differences for glucose, fructose and sucrose in accordance with the three $\mathrm{Zn}$ nutrition statuses, being the deficient status the one with the higher concentration presenting increases of $15 \%, 18 \%$ and $19 \%$ respectively compared to the normal nutrition status which presented minimum concentrations (Figure 5, $P<0.001$ ). There is little information for us to compare our results in regards to $\mathrm{Zn}$ nutrition status and its relationship with nonstructural carbohydrates concentration on pecan tree leaves. However, it is known that sucrose is extremely important to achieve pecan tree acclimatization to stress due to $\mathrm{Zn}$ deficiency [22]. This carbohydrate is one of the main photosynthesis products of pecan trees and the main form on which carbohydrates are shifted from the leaves to the rest of the plant. [15] mentions that high foliage concentration of nonstructural carbohydrates with $\mathrm{Zn}$ nutrition deficiencies is due to a growth of poor shoots, therefore $\mathrm{Zn}$ nutrition status can determine sucrose accumulation and distribution with the plant. This idea matches with the results obtained on our study. On previous studies mentioned by [18] where the relationships between chlorophyll a and total foliage soluble carbohydrates were studied, determination coefficients higher than 0.92 were found, such confirms the function of chlorophyll in carbohydrate synthesis. [21] mentions that carbohydrate reserve compensates for the low photosynthates due to stress conditions caused by $\mathrm{Zn}$ conditions, considering that in the case of pecan trees, they require large amounts of carbohydrates to keep the biomass alive and face stress conditions.

Since the results obtained on this study match with what was reported by [15] 
[18] [21] and [22], we can say that nonstructural carbohydrates present on pecan tree leaves can be considered good bioindicators in terms of $\mathrm{Zn}$ nutrition status.

\section{Conclusions}

Zn deficient nutrition status was characterized by minimum photosynthetic pigments and proteins concentrations and by maximum amino acid and nonstructural carbohydrate concentrations. While normal Zn nutrition status presented maximum photosynthetic and protein concentration status and minimum concentrations for amino acids and carbohydrates. On the other hand, intermediate $\mathrm{Zn}$ nutrition status was characterized by presenting a medium level compared to the other two $\mathrm{Zn}$ nutrition statuses. This behavior can be attributed to the registered low level of $\mathrm{Zn}$. Finally, it is important to mention that pigments, proteins, amino acids and nonstructural carbohydrates may be good physiological indicators related to $\mathrm{Zn}$ nutrition status.

\section{References}

[1] Flores-Córdova, M.A., Berzosa-Vásquez, P., Sánchez-Chávez, E., Solís, J.S., Guerrero-Morales, S. and Hernández-Carrillo, J. (2016) Composición fisicoquímica y capacidad antioxidante del fruto del pecanero en condiciones de año de elevada producción (“on”) y de año de baja producción (“off”). ITEA, 112, 255-270.

[2] SIAP-SAGARPA. (2016) Servicio de Información Agroalimentaria y Pesquera. Secretaría de Agricultura, Ganadería, Desarrollo Rural, Pesca y Alimentación.

[3] Ojeda-Barrios, D.L., Hernández-Rodríguez, O.A., Martínez-Téllez, J., NúñezBarrios, A. and Perea-Portillo, E. (2009) Aplicación foliar de quelatos de zinc en nogal pecanero. Revista Chapingo Serie Horticultura, 15, 205-210. https://doi.org/10.5154/r.rchsh.2009.15.028

[4] Escudero-Almanza, D.J., Ojeda-Barrios, D.L., Martínez-Téllez, J., Guerrero-Prieto, V.M., Ruíz Anchondo, T. and Sánchez-Chávez, E. (2012) Actividad de anhidrasa carbónica como indicador bioquímico de zinc en plántulas de nogal pecanero. In: Nutrición mineral de las plantas como base de una agricultura sostenible, Madrid, 111-116.

[5] Vargas, P.G. and Arreola, A.J (2008) Respuesta del nogal pecanero (Carya illinoensis $\mathrm{K}$. Koch) a las aplicaciones foliares de nutrimentos. Revista Chapingo Serie Zonas Áridas, 7, 7-14.

[6] Ojeda-Barrios, D., Abadía, J., Lombardini, L., Abadía, A. and Vázquez, S. (2012) Zinc Deficiency in Field-Grown Pecan Trees: Changes in Leaf Nutrient Concentrations and Structure. Journal of the Science of Food and Agriculture, 92, 1672-1678. https://doi.org/10.1002/jsfa.5530

[7] Barrameda-Medina, Y., Montesinos-Pereira, D., Romero, L., Ruiz, J.M. and Blasco, B. (2014) Comparative Study of the Toxic Effect of Zn in Lactuca sativa and Brassica oleracea Plants: I. Growth, Distribution, and Accumulation of Zn, and Metabolism of Carboxylates. Environmental and Experimental Botany, 107, 98-104. https://doi.org/10.1016/j.envexpbot.2014.05.012

[8] Mousavi, S.R. (2011) Zinc in Crop Production and Interaction with Phosphorus. Australian Journal of Basic and Applied Sciences, 5, 1503-1509.

[9] Broadley, M.R., White, P.J., Hammond, J.P., Zelko, I. and Lux, A. (2007) Zinc in 
Plants. New Phytologist, 173, 677-702.

https://doi.org/10.1111/j.1469-8137.2007.01996.x

[10] Ojeda-Barrios, D.L., Bayona, J.A., Lombardini, L., Abadía, A., Vázquez, S. and Martínez, J. (2013) Aspectos nutricionales relacionados a estrés abiótico en nogal pecanero. In XIV Simposio internacional de nogal pecanero, p. 24.

[11] Núñez-Moreno, H., Walworth, J.L., Pond, A.P. and Kilby, M.W. (2009) Soil Zinc Fertilization of "Wichita" Pecan Trees Growing under Alkaline Soil Conditions. Hort Science, 44, 1736-1740.

[12] Cakmak, I. (2000) Transley Review No. 111 Possible Roles of Zin in Protecting Plant Cells from Damage by Reactive Oxygen Species. The New Phytologist, 146, 185-205. https://doi.org/10.1046/j.1469-8137.2000.00630.x

[13] Gil, A.I., Marroquín, M. and Martínez, L. (2012) Efecto del zinc sobre la inducción de ramas productivas en gulupa (Passiflora edulis Sims). Revista Colombiana de Ciencias Hortícolas, 6, 152-160. https://doi.org/10.17584/rcch.2012v6i2.1973

[14] Ojeda-Barrios, D.L., Sánchez-Chávez, E., Sida-Arreola, J.P., Valdez-Cepeda, R. and Balandran-Valladares, M. (2016) The Impact of Foliar Nickel Fertilization on Urease Activity in Pecan Trees. Journal of Soil Science and Plant Nutrition, 16, 237-247. https://doi.org/10.4067/S0718-95162016005000019

[15] Sánchez, E., Soto, J.M., Núñez, A., Ruiz, J.M. and Romero, L. (2005) Biosynthesis of Non-Structural Carbohydrates and Their Distribution in Greenbean Plants (Phaseolus vulgaris L. Cv. Strike): Deficiency vs. Toxicity of Nitrogen. Revista Fitotecnia Mexicana, 28, 55-61.

[16] Sánchez, E., Rivero, R.M., Ruiz, J.M. and Romero, L. (2004) Changes in Biomass, Enzymatic Activity and Protein Concentration in Roots and Leaves of Green Bean Plants (Phaseolus vulgaris L. cv. Strike) under High NH4 NO3 Application Rates. Scientia Horticulturae, 99, 237-248. https://doi.org/10.1016/S0304-4238(03)00114-6

[17] SAS (2002) SAS/STAT Users Guide: Statics, Version. 9.00. SAS Institute, Inc., Cary, 503.

[18] Fortes, D., Herrera, R.S., González, S., García, M., Romero, A. and Cruz, A.M. (2009) Comportamiento de los pigmentos fotosintéticos, según la edad de rebrote después del pastoreo de Pennisetum purpureum vc. Cuba CT-115 en la estación poco lluviosa. Revista Cubana de Ciencia Agrícola, 43, 183-168.

[19] Lizarazo, M.Á., Hernández, C.A., Fischer, G. and Gómez, M.I. (2013) Biomasa, parámetros foliares y sintomatología en respuesta a diferentes niveles de manganeso, zinc y boro en curuba (Passiflora tripartita var. mollissima). Revista Colombiana de Ciencias Hortícolas, 7, 31-45. https://doi.org/10.17584/rcch.2013v7i1.2033

[20] Kyrkby, E. and Römheld, V. (2008) Micronutrientes en la fisiología de las plantas: Funciones, absorción y movilidad. Informaciones Agronómicas, 68, 1-3.

[21] Martínez-Trinidad, T., Plascencia-Escalante, F.O. and Islas-Rodríguez, L. (2013) La relación entre los carbohidratos y la vitalidad en árboles urbanos. Revista Chapingo serie ciencias forestales $y$ del ambiente, 19, 459-468.

https://doi.org/10.5154/r.rchscfa.2012.03.016

[22] Martínez, D., Sabori, P.J. and Núñez, M.J. (2010) Reservas de carbohidratos en el nogal pecanero. In: XI: Simposio internacional de nogal pecanero, 95. 